\title{
Pengaruh Capital Intencity Ratio, Free Cash Flow, Kualitas Audit, dan Leverage Terhadap Manajemen Laba pada Perusahaan Manufaktur yang Terdaftar di BEI
}

\author{
Fitria Ramadhani $^{1}$, Sri Wahjuni Latifah ${ }^{2}$, Endang Dwi Wahyuni ${ }^{3}$ \\ Universitas Muhammadiyah Malang \\ ${ }^{1}$ fitriaramadhani2995@gmail.com
}

\begin{abstract}
The purpose of this research is to analyze the influence of variable capital intencity ratio, free cash flow, audit quality, and leverage to earnings management action. The population in this study is manufacturing companies listed on the BEI during the period 2013-2015. Tests on the formulation using multiple regression analysis methods contained in the SPSS program. Based on the result of this research indicate that variable of capital intencity ratio, free cash flow, and audit quality do not influence to earnings management action. While the leverage variable has an influence on earnings management. This is evidenced by the average value of high sample company leverage. Management will try to manage its profits to reduce the failure rate to pay corporate liabilities.
\end{abstract}

Keywords: Earnings Management, Capital Intencity Ratio, Free Cash Flow, Audit Quality, Leverage

\begin{abstract}
ABSTRAK
Tujuan dari penelitian ini adalah untuk menganalisis pengaruh intensitas modal variabel rasio, arus kas bebas, audit kualitas dan leverage pada manajemen laba. Populasi dalam penelitian ini adalah perusahaan manufaktur yang terdaftar di BEI selama periode 2013-2015. Alat uji yang digunakan dalam penelitian ini adalah regresi berganda menggunakan SPSS. Berdasarkan hasil penelitian ini menunjukkan bahwa variabel rasio intencity modal, arus kas bebas, dan audit kualitas tidak mempengaruhi tindakan manajemen pendapatan. Sementara variabel leverage memiliki pengaruh terhadap manajemen pendapatan. Hal ini dibuktikan dengan nilai rata-rata tinggi leverage dari sampel perusahaan. Manajemen akan mencoba untuk mengelola keuntungannya untuk mengurangi tingkat kegagalan untuk membayar kewajiban perusahaan.
\end{abstract}

Kata kunci: intensitas modal, manajemen lba, arus kas bebas, kualitas audit, leverage 


\section{PENDAHULUAN}

Perusahaan didirikan dengan tujuan untuk mencari keuntungan yang biasa disebut laba. Pada saat perusahaan berkembang menjadi besar, maka terdapat dua pihak yang ada dalam perusahaan yaitu pemilik dan pengelola perusahaan. Adanya dua pihak tersebut menyebabkan terjadinya pemisahan yang dapat menimbulkan asimetri informasi tentang perusahaan. Teori keagenan (agency theory) yang menyatakan bahwa adanya pemisahan antara pemilik dan pengelola perusahaan dapat menimbulkan masalah keagenan yaitu, ketidaksejajaran kepentingan antara pemilik (principal) dan manajemen (agent), (Ulum, 2008).

Perbedaan kepentingan digambarkan dengan adanya tindakan manajemen yang lebih mengutamakan kepentingannya yang dapat berdampak merugikan pihak pemilik dalam mengambil sebuah keputusan. Hal itu terjadi karena keterbatasan pemilik untuk mengakses informasi yang ada dalam perusahaan. Oleh karena itu, pemilik memerlukan informasi perusahaan terutama informasi keuangan. Namun informasi yang terdapat di dalam laporan keuangan belum dapat menjamin bahwa informasi tersebut mencerminkan kondisi keuangan perusahaan yang sebenarnya (Yunianto, 2013). Manajemen terkadang melakukan manajemen laba perusahaan yang dikelolanya untuk mengambil keuntungan individu. Manajemen laba merupakan suatu aktivitas manajemen yang dilakukan untuk mempengaruhi dan mengintervensi laporan keuangan (Sulistyanto, 2014).

Menurut Sulistyanto (2014) manajemen laba dilakukan dengan mempermainkan komponen-komponen akrual dalam laporan keuangan, sebab pada komponen akrual dapat dilakukan permainan angka melalui metode akuntansi yang digunakan sesuai dengan keinginan orang yang melakukan pencatatan dan penyusunan laporan keuangan. Manajer dapat mempermainkan komponen-komponen laporan keuangan dengan menentukan atau mengubah nilai estimasi yang dipakai, dan banyak pihak yang mengatakan bahwa upaya mempermainkan laporan keuangan tersebut dapat dilakukan karena diakomodasi dan difasilitasi oleh prinsip akuntansi.

Salah satu contoh dari manajemen laba adalah dengan mengendalikan transaksi akrual yang terjadi di perusahaan. Permainan transaksi akrual bisa dilakukan melalui akun aset tetap yang dimiliki oleh perusahaan. Untuk melihat proporsi aset tetap yang dimiliki dapat dilakukan dengan menggunakan perhitungan rasio-rasio, salah satunya adalah capital intencity ratio (CIR). Menurut Putri dan Lautania (2016) capital intensity ratio atau rasio intensitas aset tetap adalah perbandingan aset tetap terhadap total aset sebuah perusahaan. Rasio intensitas aset tetap menggambarkan proporsi aset tetap perusahaan pada keseluruhan aset yang dimiliki sebuah perusahaan. Perusahaan dengan capital intensity ratio (CIR) yang lebih tinggi akan memiliki kecenderungan untuk melakukan memanipulasi dengan tujuan memperoleh laba (Santoso dkk., 2016). 
Selain itu, manajemen laba juga terjadi pada objek lainnya seperti aset lancar perusahaan. Salah satu aset lancar perusahaan yang sangat mudah dimanipulasi adalah kas. Arus kas bebas adalah sisa kas yang sudah diatribusikan kepada investor dan digunakan untuk investasi lainnya. Perusahaan dengan arus kas bebas (free cash flow) yang tinggi akan memiliki kesempatan yang besar untuk melakukan manajemen laba. Menurut White et al. (2003:68) dalam Agustia (2013) semakin besar free cash flow yang tersedia dalam suatu perusahaan, maka semakin sehat perusahaan tersebut karena memiliki kas yang tersedia untuk pertumbuhan, pembayaran hutang, dan dividen. Hasil penilitian dari Agustia (2013) menyatakan free cash flow berpengaruh negatif pada manajemen laba karena tanpa ada manajemen laba pun, perusahaan sudah bisa meningkatkan harga saham dengan memiliki arus kas bebas yang tinggi.

Adapun solusi untuk mendeteksi apakah pihak manajemen perusahaan melakukan manajemen laba atau tidak adalah dengan melakukan audit. Perusahaan melakukan audit eksternal untuk meyakinkan pihak pemilik (principal) bahwa informasi yang disajikan oleh manajemen telah sesuai dengan prinsip-prinsip akuntansi yang berterima umum. Audit eksternal dilakukan oleh auditor yang berasal dari Kantor Akuntan Publik (KAP). Namun hal tersebut belum menjamin apakah bisa membuat manajemen menghindari praktik manajemen laba, karena hasil audit yang baik terpenuhi apabila ada independensi antara pihak perusahaan dan KAP. Oleh karena itu, auditor memiliki peran penting dalam meningkatkan pengawasan pada perusahaan. Dengan adanya hasil audit yang berkualitas akan berdampak positif bagi tata kelola perusahaan, karena akan mempersempit kesempatan manajemen untuk melakukan praktik manajemen laba. Menurut Yunianto (2013) menyatakan bahwa kualitas audit memiliki hubungan yang tidak signifikan dengan manajemen laba.

Objek manajemen laba lainnya adalah akun-akun yang terdapat pada liabilitas, yaitu liabilitas lancar. Sebagian dari aktivitas liabilitas lancar berkaitan dengan aset lancar yang artinya semakin besar transaksi yang menimbulkan aset lancar semakin besar pula kemungkinan perusahaan untuk memiliki liabilitas lancar (Sulistyanto,2014). Untuk mengukur proporsi utang lancar yang dimiliki perusahaan terhadap aset lancar yang dimiliki, yaitu dengan rasio leverage. Rasio ini mempresentasikan apakah perusahaan mempunyai nilai yang cukup pada aset lancar untuk mengcover utang lancar yang dimiliki. Menurut Agustia (2013), perusahaan yang mempunyai leverage yang tinggi, berarti proporsi hutangnya lebih tinggi dibandingkan dengan proporsi asetnya sehingga akan cenderung melakukan manipulasi dalam bentuk manajamen laba. Sedangkan menurut Kosasih dan Widayati (2013) menyatakan leverage yang semakin tinggi memiliki arti bahwa perusahaan memiliki hutang yang lebih besar daripada asetnya, sehingga ada pihak eksternal lainnya yaitu kreditor yang turut mengawasi pelaporan keuangan perusahaan. Dengan bertambahnya pihak eksternal yang turut 
ikut mengawasi, membuat pengawasan semakin ketat sehingga fleksibelitas manajemen untuk melakukan manajemen laba semakin berkurang.

\section{TINJAUAN LITERATUR DAN PERUMUSAN HIPOTESIS}

Capital Intencity Ratio (CIR) atau rasio intensitas modal adalah aktivitas investasi yang dilakukan perusahaan yang dikaitkan dengan investasi dalam bentuk aset tetap (intensitas modal). Perusahaan dengan Capital Intensity Ratio (CIR) yang lebih tinggi akan memiliki kecenderungan untuk melakukan memanipulasi dengan tujuan memperoleh laba (Santoso dkk., 2016).

\section{$\mathrm{H}_{1}$ : capital intencity ratio berpengaruh terhadap manajemen laba.}

Free cash flow merupakan determinan penting dalam penentuan nilai perusahaan, sehingga manajer perusahaan lebih terfokus pada usaha untuk meningkatkan free cash flow (Sawir, 2004:94). Menurut White et al. (2003:68) dalam Agustia (2013) semakin besar free cash flow yang tersedia dalam suatu perusahaan, maka semakin sehat perusahaan tersebut karena memiliki kas yang tersedia untuk pertumbuhan, pembayaran hutang, dan dividen. Hasil penilitian dari Agustia (2013) menyatakan free cash flow berpengaruh negatif pada manajemen laba karena tanpa ada manajemen laba pun, perusahaan sudah bisa meningkatkan harga saham dengan memiliki arus kas bebas yang tinggi. Sedangkan Kangarluei et al. (2011) menyatakan bahwa besar kecilnya nilai FCF suatu perusahaan tidak mempunyai pengaruh secara signifikan terhadap kemungkinan terjadinya manajemen laba. Berdasarkan uraian tersebut, dalam penelitian ini diajukan hipotesis sebagai berikut:

\section{$\mathrm{H}_{2}$ : free cash flow berpengaruh terhadap manajemen laba.}

Auditor merupakan peran penting dalam meningkatkan pengawasan pada perusahaan. Dengan adanya hasil audit yang berkualitas akan berdampak pada tata kelola perusahaan karena akan mempersempit kesempatan manajemen untuk melakukan praktik manajemen laba. Menurut Yunianto (2013) menyatakan bahwa kualitas audit tidak berpengaruh dan memiliki hubungan yang tidak signifikan dengan manajemen laba. Sedangkan menurut Becker et al. (1998) dalam Yunianto (2013) mengemukakan bahwa kualitas audit yang rendah membiarkan terjadinya penaikan laba melalui akrual kebijakan (discretionary accrual). Berdasarkan uraian tersebut, dalam penelitian ini diajukan hipotesis sebagai berikut:

\section{$\mathrm{H}_{3}$ : Kualitas audit berpengaruh terhadap manajemen laba.}

Menurut Agustia (2013), perusahaan yang mempunyai leverage yang tinggi, berarti proporsi hutangnya lebih tinggi dibandingkan dengan proporsi asetnya akan cenderung melakukan manipulasi dalam bentuk manajamen laba. Sedangkan menurut Kosasih dan Widayati (2013) menyatakan leverage yang 
semakin tinggi memiliki arti bahwa perusahaan memiliki hutang yang lebih besar daripada asetnya, sehingga ada pihak eksternal lainnya yaitu kreditor yang turut mengawasi pelaporan keuangan perusahaan. Dengan bertambahnya pihak eksternal yang turut ikut mengawasi, membuat pengawasan semakin ketat sehingga fleksibelitas manajemen untuk melakukan manajemen laba semakin berkurang. Berdasarkan uraian tersebut, dalam penelitian ini diajukan hipotesis sebagai berikut:

\section{$\mathrm{H}_{4}$ : leverage berpengaruh terhadap manajemen laba.}

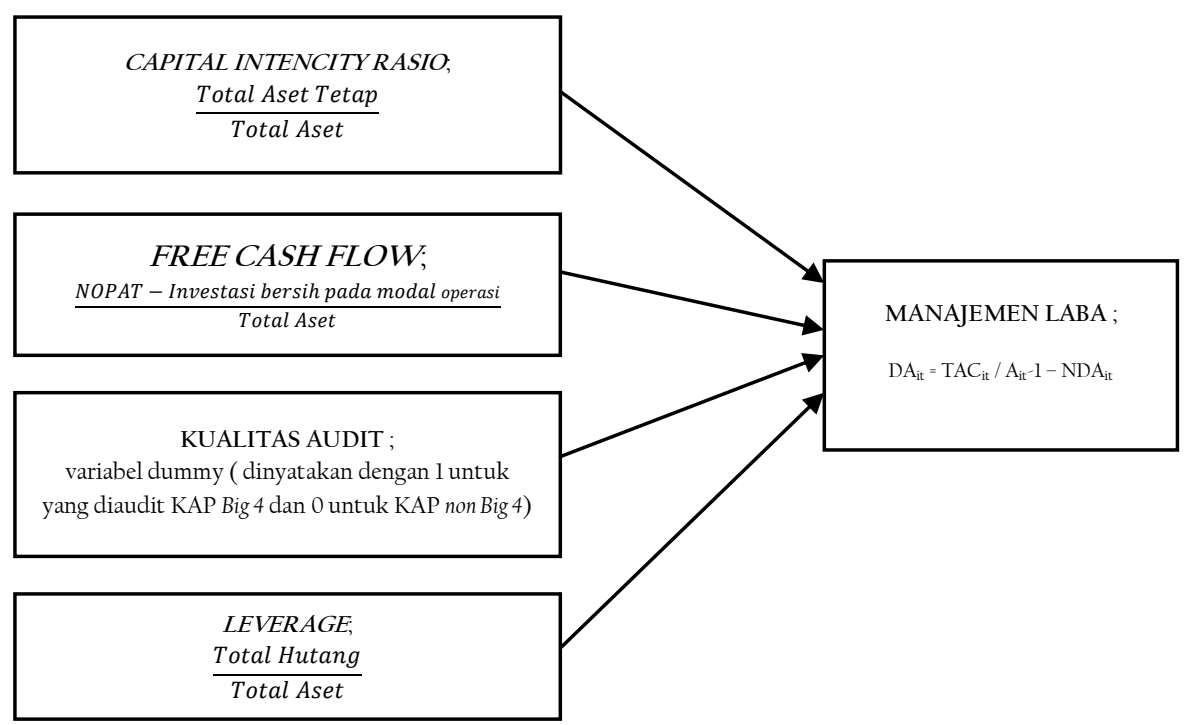

Gambar 1. Kerangka Pikir

\section{METODE PENELITIAN}

Penelitian ini merupakan penelitian asosiatif kuantitatif dengan menggunakan populasi perusahaan manufaktur yang terdaftar di BEI selama periode 2013-2015 dan pengambilan sampel melauli purposive sampling. Manajemen laba dalam penelitian ini diukur dengan discretionary accrual menggunakan Modified Jones Model. Penelitian ini menguji pengaruh beberapa variabel yaitu capital intencity ratio (CIR), free cash flow (FCF), kualitas uudit (AUD), dan leverage (LEV), terhadap praktik manajemen laba (DA).

Metode analisis data menggunakan metode analisis regresi berganda (multiple regression analysis). Analisis statistik deskriptif digunakan untuk menjelaskan tiap variabel yang digunakan. Uji asumsi klasik digunakan untuk mendeteksi bahwa distribusi data yang digunakan adalah normal dan model tidak mengandung gejala multikolinearitas, autokorelasi, dan heteroskedastisitas. Uji koefisien determinasi dan uji $\mathrm{F}$ untuk menguji kecocokan model (goodness of fit test) dan uji t (parsial) untuk melihat pengaruh variabel independen terhadap variabel dependen. 


\section{HASIL DAN PEMBAHASAN}

Berdasarkan hasil dari purposive sampling dan prosedur penyampelan diperoleh sebanyak 100 perusahaan dengan total 300 perusahaan yang digunakan sebagai sampel dalam tahun pengamatan. Proses pemilihan sampel sesuai dengan purposive sampling bisa dilihat pada Tabel 1.

Tabel 1. Purposive Sampling

\begin{tabular}{lcc}
\hline \multicolumn{1}{c}{ Keterangan } & Jumlah \\
\hline 1. Perusahaan manufaktur yang terdaftar di BEI tahun 2013-2015. & 148 \\
2. Perusahaan yang tidak mempublikasikan laporan keuangan auditan dari tahun & $(16)$ \\
$2012-2015$. & $(6)$ \\
3. Perusahaan yang tidak menyediakan data laporan keuangan perusahaan dan data & \\
$\quad \begin{array}{l}\text { untuk perhitungan variabel tersedia secara lengkap untuk tahun pelaporan dari } \\
2013 \text { sampai 2015. }\end{array}$ & $(26)$ \\
4. Perusahaan yang tidak menerbitkan laporan keuangan dengan mata uang rupiah. & 100 \\
Jumlah data akhir & 3 \\
Tahun penelitian & 300 \\
\hline
\end{tabular}

\section{ANALISIS STATISTIK DESKRIPTIF}

Dari hasil analisis frekuensi, perusahaan yang diaudit oleh KAP Big 4 adalah sebanyak 108 dalam jumlah sampel atau dengan kata lainnya hanya sebesar 36\% dari jumlah seluruh perusahaan. Sedangkan perusahaan yang diaudit oleh KAP Non Big 4 adalah sebanyak 192 dalam jumlah sampel atau dengan kata lainnya hanya sebesar $64 \%$ dari jumlah seluruh perusahaan. Sedangkan hasil dari statistik deskiptif menunjukkan variabel dependen yaitu manajemen laba yang diproksikan dengan decreationary accruals dimana manajemen laba dilakukan dengan menurunkan laba yang diindikasikan oleh nilai negatif pada mean. Nilai minimum manajemen laba dimiliki oleh perusahaan KLBF pada tahun 2014 sebesar $-6,94$ atau $-694 \%$ yang menunjukkan tindakan menurunkan laba dengan menyajikan laba lebih rendah, sedangkan nilai maksimum dimiliki oleh perusahaan SULI pada tahun 2015 yaitu sebesar 0,78 atau $78 \%$ yang mengindikasikan menyajikan laba lebih tinggi. Nilai rata-rata (mean) descreationary accruals adalah sebesar $-1,22$ atau $-122 \%$ hasil tersebut menunjukkan bahwa rata-rata perusahaan melakukan tindakan manajemen laba dengan menyajikan laba lebih rendah.

Pada variabel CIR Nilai minimum 0,001 atau $0,1 \%$ dimiliki oleh perusahaan SIAP pada tahun 2014 dan nilai maksimum dimiliki oleh perusahaan KBRI yaitu sebesar 0,948 atau $94,8 \%$ pada tahun 2012. Nilai minimum pada variabel FCF sebesar $-6,462$ atau $-646,2 \%$ dimiliki oleh perusahaan MYTX di tahun 2012 dan nilai maksimum dimiliki oleh perusahaan SIAP yaitu sebesar 21,622 atau $2.162,2 \%$ di tahun 2014. Nilai minimum yang ada pada variabel LEV adalah sebesar 0,037 atau 3,7\% dimiliki oleh perusahaan JPRS pada tahun 2013 dan nilai 
maksimum dimiliki oleh perusahaan BIMA yaitu sebesar 2,876 atau 287,6\% pada tahun 2012.

\section{HASIL UJI NORMALITAS}

Hasil uji normalitas menggunakan grafik normal probability plot yang menunjukkan titik-titik menyebar disekitaran garis diagonal yang berarti data yang digunakan normal dan hasil tersebut divalidasi dengan hasil uji statistik Kolmogrov-Smirnov dengan nilai sebesar 0.995 dan signifikan 0.321. Karena siginfikansi melebih dari 0.05 (karena $\mathrm{p}=0.321>0.05$ ). Jadi data penelitian dapat dikatakan terdistribusi secara normal.

\section{HASIL UJI R ${ }^{2}$ ATAU KOEFISIEN DETERMINASI}

Hasil analisis data mengindikasikan nilai adjusted $\mathrm{R}^{2}$ pada penelitian ini pada tabel 4 adalah sebesar 0.059 yang berarti variabilitas variabel dependen dapat dijelaskan oleh variabilitas variabel independen sebesar 5,9\% dari model regresi yang dipakai. Sedangkan $94,1 \%$ dijelaskan oleh variabel lain yang tidak termasuk dalam penelitian ini.

\begin{tabular}{ccrr}
\multicolumn{4}{c}{ Tabel 2. Hasil $\mathrm{Uji}^{2}$ atau Koefisien Determinasi } \\
\hline Model & $\mathrm{R}$ & $\mathrm{R}$ Square & Adjusted R Square \\
1 &, $297^{\mathrm{a}}$ &, 088 &, 059 \\
\hline
\end{tabular}

\section{HASIL UJI HIPOTESIS}

Pengujian hipotesis pada penelitian ini dilakukan secara simultan (uji F) dan parsial (uji t). Uji $\mathrm{F}$ digunakan untuk melihat pengaruh simultan variabel independen terhadap variabel dependen sedangkan uji $t$ digunakan untuk menghitung masing-masing variabel bebas yang digunakan dalam penelitian ini secara parsial. Pada uji ini hipotesis 1 sampai dengan 5 atau H1 sampai dengan H5 diuji dengan menggunakan uji t.

\section{Uji F}

Uji F merupakan uji pengaruh simultan yang digunakan untuk mengetahui variabel indipenden secara bersama-sama atau simultan mempengaruhi variabel dependen.

Tabel 3 Hasil Uji F

\begin{tabular}{llrrrrr}
\hline \multicolumn{7}{c}{ ANOVA $^{\mathbf{a}}$} \\
\hline \multicolumn{2}{l}{ Model } & Sum of Squares & Df & Mean Square & F & Sig. \\
1 & Regression & 18,592 & 4 & 4,648 & 3,064 &, $019^{\mathrm{b}}$ \\
& Residual & 192,634 & 295 & 1,517 & & \\
& Total & 211,225 & 299 & & & \\
\hline
\end{tabular}
a. Dependent Variable: LnDA
b. Predictors: (Constant), LEV, FCF, AUD, CIR 
Dapat dilihat pada tabel 5 hasil dari nilai $F_{\text {hitung }}$ sebesar 3,064 dan signifikan pada 0,019. Nilai $F_{\text {tabel }}$ dengan df4 df1 300 pada taraf 5\% sebesar 2,402. Karena $F_{\text {hitung }}>F_{\text {tabel }}(3,064>2,402)$ dan signifikansi 0,019 yang berarti kurang dari 0,05 sehingga variabel independen CIR, FCF, AUD, dan LEV secara simultan mempengaruhi descreationary accruals.

\section{Uji t}

Tabel 4 Hasil Uji t

\begin{tabular}{cccccc}
\hline $\begin{array}{c}\text { Variabel } \\
\text { Bebas }\end{array}$ & Beta & $\mathbf{t}_{\text {hitung }}$ & Sig. & $\mathbf{t}_{\text {tabel }}$ & Keterangan \\
\hline CIR & 0,203 & 0,353 & 0,724 & 1,968 & Tidak Berpengaruh \\
FCF & 1,745 & 1,119 & 0,265 & 1,968 & Tidak Berpengaruh \\
AUD & $-0,203$ & $-0,839$ & 0,403 & 1,968 & Tidak Berpengaruh \\
LEV & 1,314 & 3,046 & 0,003 & 1,968 & Berpengaruh \\
\hline
\end{tabular}

Hasil penelitian menunjukkan pengaruh variabel capital intencity ratio terhadap manajemen laba dengan nilai $t_{\text {hitung }}$ sebesar $0,353<t_{\text {tabel }} 1,968$ dan nilai signifikansi sebesar 0,724 yang berarti lebih besar dari nilai signifikasi 0,05,maka variabel independen capital intencity ratio tidak berpengaruh terhadap manajemen laba sehingga $\mathrm{H}_{1}$ ditolak. Nilai yang positif menunjukkan bahwa variabel bebas mempunyai hubungan yang searah dengan variabel terikat sehingga semakin tinggi capital intencity ratio yang ada diperusahaan semakin tinggi pula manajemen laba yang dilakukan.

Hasil penelitian ini tidak searah dengan hasil dari penelitian Santoso dkk. (2016) yang menyatakan perusahaan dengan Capital Intensity Ratio (CIR) yang lebih tinggi akan memiliki kecenderungan untuk melakukan memanipulasi dengan tujuan memperoleh laba. Hal ini dibuktikan dengan nilai mean pada uji statistik deskriptif yang menunjukkan rata-rata nilai CIR pada perusahaan sampel hanya sebesar 0,375 atau $37,5 \%$ dari seluruh total aset perusahaan yang dimiliki dimana nilai tersebut cukup rendah. Dengan begitu bisa dikatakan perusahaan rata-rata memiliki jumlah aset tetap yang sedikit. Dengan demikian jumlah aset tetap yang sedikit tersebut tidak memengaruhi motivasi manajemen untuk melakukan praktik manajemen laba yang dapat dilakukan dengan mengubah metode penyusutan pada akun aset tetap yang dimiliki. Dilihat dari 300 sampel yang ada hanya 2 perusahaan yang memiliki CIR yang tinggi yaitu PT. Kertas Basuki Rachmat Indonesia Tbk dan PT. Sekar Bumi Tbk pada tahun 2012 sedangkan perusahaan sampel lainnya kecil. Perusahaan dengan nilai capital intencity ratio yang tinggi akan memiliki kecenderungan untuk melakukan manipulasi dengan tujuan memperoleh laba. Tetapi hal tersebut tidak terjadi pada perusahaan manufaktur yang menjadi sampel penelitian karena rata-rata memiliki nilai CIR yang rendah.

Hasil penelitian menunjukan bahwa variabel free cash flow tidak berpengaruh terhadap manajemen laba dengan nilai $t_{\text {hitung }} 1,119<t_{\text {tabel }}$ sebesar 
1,968 dan nilai signifikansi sebesar 0,265 yang berarti lebih besar dari nilai signifikan 0,05, maka free cash flow tidak berpengaruh terhadap manajemen laba sehingga $\mathrm{H}_{2}$ ditolak. Nilai yang positif menunjukkan bahwa variabel bebas mempunyai hubungan yang searah dengan variabel terikat sehingga semakin tinggi free cash flow yang ada diperusahaan semakin tinggi pula manajemen laba yang dilakukan. Hasil ini penelitian ini sejalan dengan hasil penelitian Kangarluei et al. (2011) yang menyatakan bahwa besar kecilnya nilai FCF suatu perusahaan tidak mempunyai pengaruh secara signifikan terhadap kemungkinan terjadinya manajemen laba. Hal ini dibuktikan dengan hasil uji statistik deskriptif dimana nilai mean atau rata-rata pada uji statistik deskriptif dari variabel ini adalah sebesar 0,148 atau $14,8 \%$ yang berarti sangat rendah.

Perusahaan dengan free cash flow berlebih akan memiliki kinerja yang lebih baik dibandingkan perusahaan lainnya karena mereka dapat memperoleh keuntungan atas berbagai kesempatan yang mungkin tidak dapat diperoleh perusahaan lain. Akan tetapi, besar dan kecilnya nilai FCF tidak memengaruhi manajer untuk melakukan manipulasi laba karena arus kas bebas adalah keadaan perusahaan memiliki kesempatan untuk menggunakan arus kas yang tidak terpakai. Walaupun arus kas bebas yang dihasilkan besar atau kecil, hal tersebut sama-sama menunjukkan bahwa perusahaan telah menjalankan operasionalnya dengan baik sehingga tidak perlu melakukan manajemen laba untuk membuat nilai perusahaan menjadi naik. Pada 300 sampel yang ada hanya ada 4 perusahaan yang memiliki nilai FCF yang tinggi yaitu PT. Sekawan Intipratama Tbk, PT. Argo Pantes Tbk, PT. Apac Citra Centertex Tbk, dan PT. Indocement Tunggal Prakarsa Tbk. Nilai free cash flow yang tinggi dapat mengakibatkan salah dalam penggunaannya oleh manajemen untuk melakukan manipulasi. Tetapi tidak berpengaruh pada perusahaan sampel karena nilai FCF yang dimiliki rata-rata perusahaan rendah.

Hasil penelitian menunjukkan pengaruh kualitas audit terhadap manajemen laba dengan nilai $t_{\text {hitung }}$ sebesar $-0,839<\mathrm{t}_{\text {tabel }}$ sebesar 1,968 dan nilai signifikansi sebesar 0,403 yang berarti lebih besar dari nilai signifikan 0,05, maka kualitas audit tidak berpengaruh terhadap manajemen laba sehingga $\mathrm{H}_{3}$ ditolak. Nilai yang negatif menunjukkan bahwa variabel bebas mempunyai hubungan yang tidak searah dengan variabel terikat sehingga semakin tinggi kualitas audit yang ada diperusahaan semakin rendah pula manajemen laba yang dilakukan. Hasil penelitian ini sejalan dengan hasil penelitian yang dilakukan Yunianto (2013) yang menyatakan bahwa kualitas audit tidak berpengaruh dan memiliki hubungan yang tidak signifikan dengan manajemen laba. Kualitas audit dalam penelitian ini diukur dengan ukuran KAP karena diasumsikan akan berpengaruh terhadap hasil audit yang dilakukan oleh auditornya namun hal tersebut belum menjamin penekanan pada praktik manajemen laba yang dilakukakan perusahaan. Dari hasil analisis frekuensi menunjukkan perusahaan sampel lebih banyak diaudit oleh $K A P$ 
Non Big 4 yang berarti baik KAP Big 4 maupun Non Big 4 melakukan audit dengan baik dan dikarenakan hubungan KAP dengan perusahaan cukup unik sehingga KAP menghindari konflik dengan perusahaan.

Hasil penelitian menunjukkan bahwa leverage berpengaruh terhadap manajemen laba yang ditunujukkan oleh nilai $\mathrm{t}_{\text {hitung }}$ sebesar 3,406 $>\mathrm{t}_{\text {tabel }}$ sebesar 1,968 dan nilai signifikansi sebesar 0,003 yang berarti lebih kecil dari nilai signifikan 0,05, maka variabel leverage berpengaruh terhadap manajemen laba sehingga $\mathrm{H}_{4}$ diterima. Nilai yang positif menunjukkan bahwa variabel bebas mempunyai hubungan yang searah dengan variabel terikat sehingga semakin tinggi leverage yang ada diperusahaan semakin tinggi pula manajemen laba yang dilakukan. Hasil penelitian ini sejalan dengan hasil penelitian Agustia (2013) bahwa perusahaan yang mempunyai leverage yang tinggi, berarti proporsi hutangnya lebih tinggi dibandingkan dengan proporsi asetnya akan cenderung melakukan manipulasi dalam bentuk manajamen laba. Dari uji analisis deskriptif nilai mean atau rata-rata pada uji statistik deskriptif dari leverage adalah sebesar 0,510 atau $51 \%$ sehingga tingkat leverage yang menjadi perusahaan sampel memiliki nilai utang yang tinggi. Rasio leverage mengindikasikan total kewajiban lancar terhadap total aset yang dimiliki oleh perusahaan yang berarti hasil tersebut memperlihatkan bahwa $51 \%$ dari pendanaan pada aset perusahaan di dapat dari pihak kreditor.

Jika lebih banyak kewajiban lancar yang dimiliki maka hal tersebut dapat memengaruhi para kreditor untuk memberikan pinjaman kepada perusahaan sehingga pihak manajemen akan berusaha untuk memanipulasi laba bersih untuk mengurangi kemungkinan kegagalan membayar hutang-hutang perusahaan. Dari 300 sampel perusahaan, rata-rata memiliki nilai leverage yang tinggi. Beberapa perusahaan juga memiliki nilai leverage di atas 1 yaitu PT. Jakarta Kyoei Steel Works Tbk, PT. Siwani Makmur Tbk, PT. SLJ Global Tbk, PT. Apac Citra Centertex Tbk, PT. Sekar Bumi Tbk, dan PT. Primarindo Asia Infrastructure Tbk.

\section{KESIMPULAN}

Berdasarkan dari rumusan masalah, tujuan, landasan teori, hipotesis dan hasil analisis data yang telah dilakukan pada perusahaan-perusahaan manufaktur yang terdaftar di BEI dalam periode tahun 2013-2015 mengindikasikan bahwa dari hasil analisis data menyatakan bahwa capital intencity ratio tidak berpengaruh terhadap manajemen laba karena tingkat investasi pada aset yang dilakukan oleh pihak manajemen belum bisa menentukan motivasi para manajer untuk melakukan manipulasi laba berupa manajemen laba.

Dari hasi analisis juga menyatakan free cash flow tidak berpengaruh terhadap manajemen laba karena besar kecilnya nila FCF yang ada di suatu perusahaan tidak memengaruhi manajemen untuk melakukan manipulasi laba. Begitupula dengan kualitas audit tidak berpengaruh terhadap manajemen laba 
karena kualitas audit yang dilakukan oleh KAP Big 4 maupun non Big 4 samasama melakukan audit yang baik dan adanya hubungan antara KAP dan perusahaan yang unik sehingga KAP cenderung menghindari konflik dengan perusahaan.

Namun hasil analisis leverage memperlihatkan bahwa leverage berpengaruh terhadap manajemen laba. Hal ini disebabkan rasio leverage dapat mengindikasikan perusahaan dengan jumlah kewajiban yang dimiliki sehingga manajemen berusaha mengelola labanya untuk mengurangi tingkat kegagalan membayar kewajibannya yang dapat mengelabui para kreditor maupun calon kreditor.

Hal ini membuktikan bahwa keterkaitan antara teori keagenan yang menyatakan bahwa agent mempunyai kesempatan untuk mengutamakan kepentingan yang menguntungkanya di luar kepentingan principal dalam hal pelaporan keuangan yang menghasilkan asimetris informasi kepada pemangku kepentingan sehingga membuat para pemilik salah dalam mengambil keputusan memang benar terjadi.

\section{SARAN}

Saran yang dapat disampaikan berdasarkan penelitian ini adalah untuk penelitian selanjutnya sebaiknya menambah variabel yang akan diteliti seperti kondisi keuangan dengan data non keuangan yang lebih banyak sehingga hasil penelitian akan lebih baik dalam memprediksi manajemen labadengan lebih tepat. Bagi para investor yang ingin berinvestasi disarankan untuk memperhatikan informasi keuangan selain laba yang dicantumkan oleh perusahaan pada laporan keuangan perusahaan, untuk melihat kelangsungan usaha entitas yang bersangkutan dengan memperhatikan informasi keuangan tahun sebelumnya.

\section{DAFTAR PUSTAKA}

Agustia, Dian. 2013. "Pengaruh Faktor Good Corporate Governance, Free Cash Flow, dan Leverage Terhadap Manajemen Laba". Jurnal Akuntansi dan Keuangan, Vol. 15 (1),27-42.

Arieska, Metha dan Barbara Gunawan. 2011. "Pengaruh Aliran Kas Bebas dan Keputusan Pendanaan terhadap Nilai Pemegang Saham dengan Set Kesempatan Investasi dan Dividen sebagai Variabel Moderasi”. Jurnal Akuntansi dan Keuangan Vol. 13, No. 1, Mei 2011: 13-23.

Becker, C. L., M. L. Defond., J. Jiambalvo, dan K. R. Subramanyam.1998. The effect of audit quality on earnings manajement.Contemporary Accounting Research, 15 (1), 1-24. 
Brigham dan Houston. 2014. Dasar-Dasar Manajemen Keuangan.Jakarta: Salemba Empat.

Fanani, Zaenal dkk. 2009. Faktor-faktor Penentu Kualitas Pelaporan Keuangan dan Kepercayaan Investor. Jurnal akuntansi. Universitas AirlanggaSurabaya.

Ghozali, Imam. 2006. Aplikasi Analisis Multivariate dengan Program SPSS. Cet. IV. Semarang: Badan Penerbit Universitas Diponegoro.

Kangarluei, S.J., Morteza, M., and Taher, A. (2011). The Investigation And Comparison Of Free Cash Flows In The Firms Listed In Tehran Stock Exchange (Tse) With An Emphasis On Earnings Management. Int. Journal of Eco-nomics and Business Modeling, 2(2), 118-1123.

Kasmir. 2011. Analisis Laporan Keuangan. Jakarta: PT. Raja Grafindo Persada.

Kompasiana.com. 2015. "Kasus Kimia Farma (Etika Bisnis)". http://googleweblight.com/?lite_url=http://m.kompasiana.com/www.boboto h_pas20.com/kasus-kimia-farma-etikabisnis 5535b4d46ea8349b26da42eb\&ei $=1-$ SvshqF\&lc=en$\underline{\text { ID\&s}=1 \& m=481 \& \text { host }=w w w . g o o g l e} \cdot$ co.id\&ts=1488509817\&sig=AJsQQ1 DC8uHOELLgm5kmRcx0zV025zMldQ. [diakses pada 23 Februari 2017]

Kosasih, F.N. dan Widayati, C.2013. "Pengaruh Independensi Komite Audit, Efektivitas Komite Audit Dan Leverage Terhadap Praktik Manajemen Laba Pada Perusahaan Di Sektor Industri Manufaktur Yang Terdaftar Di BEI Periode 2009-2011".Jurnal Akuntansi, Vol. 17(1),132-148.

Mayangsari, S.2003.Analisis Pengaruh Independensi, Kualitas Audit, Serta Mekanisme Cororate Governance Terhadap Integritas Laporan Keuangan. Simposium Nasional Akuntansi VI, Surabaya, 16-17 Oktober, 2003, hal: 1255-1269.

Novianasari, K. 2016. "Manajemen Laba Dan Contoh Kasus Yang Ada Di Indonesia".http://taekwondo-icky.blogspot.co.id/2016/12/manajemen-labadan-contoh-kasus-yang.html?m=1. [diakses pada 23 Februari 2017]

Putri, C.L. dan Lautania, M.F. 2016. "Pengaruh Capital Intensity Ratio, Inventory Intensity Ratio, Ownership Structure dan Profitability Terhadap Effective Tax Rate (ETR)". Jurnal Ilmiah Mahasiswa Ekonomi Akuntansi (JIMEKA), Vol. 1 No. 1, 101-119.

Ross, S.A., R.W. Westerfield, dan B.D. Jordan.2008.Corporate Finance Fundamentals.McGrwa-Hill.New York. Terjemahan A.A. Yulianto, R. Yuniasih, dan Christine.2009.Pengantar Keuangan Perusahaan.Edisi Kedelapan.Jakarta:Salemba Empat. 
Santoso A., Puspitasari D., \& Widyaswati R.2016."Pengaruh Capital Intencity, Size, Earnings Per Share EPS, Debt To Equity Ratio, Dividen Payout Ratio Terhadap Manajemen Laba”. Jurnal Fokus Ekonomi, Vol. 11 No. 1, hlm:85111.

Sawir, Agnes. (2004). Kebijakan Pendanaan dan Restrukturisasi Perusahaan. Jakarta: PT. Gramedia Pustaka Utama.

Suartawan, I. Gst. Ngr. P. A. Dan Yasa, G. W. 2016. "Pengaruh Investment Opportunity Set dan Free Cash Flow Pada Kebijakan Dividen Dan Nilai Perusahaan”. E-Jurnal Akuntansi Universitas Udayana. 14.3, 2014-2044.

Sulistyanto, S. 2014. Manajemen Laba : Teori dan Model Empiris. Jakarta: Grasindo.

Susanti .2013. Pengaruh Leverage, Likuiditas, Ukuran Perusahaan, Dan Kualitas Audit Terhadap Kualitas Informasi Laporan Keuangan (Studi empiris pada perusahaan Properti dan Real Estate yang terdaftar di Bursa Efek Indonesia). Jurnal Akuntansi,Vol. 1 No.2 Desember 2013.

Sutikno .2014. Pengaruh Corporate Governance Dan Ukuran Perusahaan Terhadap Manajemen Laba Di Industri Perbankan Indonesia. Jurnal Ilmu Dan Riset Akuntansi,Vol. 3 No. 10.

Ulum, I. 2008. Akuntansi Sektor Publik. Malang: UMM Press.

Ulum, I. \& A. Juanda.2016. Metodelogi Penelitian Akuntansi: Klinik Skripsi Edisi 2. Malang: Aditya Media Publishing.

White, G.I.,Shondi, A.C., and Dov, F.2003.The Analysis and Use of Financial Statements.New York:John Wiley and Sons,Inc.

Wedari, L.K.2003. "Analisis Pengaruh Proporsi Dewan Komisaris dan Keberadaan Komite Audit Terhadap Akitivitas Manajemen Laba Pada Perusahaan Publik Di Indonesia".Tesis. Universitas Gadjah Mada.

Yunianto, Andan. 2013. "Pengaruh Penggantian Manajemen, Dewan Komisaris Independen, Kepemilikan Managerial, Kepemilikan Instutisional, dan Kualitas Audit terhadap Manajemen Laba”. Jurnal Akuntansi \& Investasi, Vol. 14 (2), 143-157. 